\title{
KONTEKSTUALITAS DALAM PENAFSIRAN MENURUT BACTIAR SURIN: MELETAKKAN RASIONALITAS SEBAGAI PERANGKAT PEMAHAMAN AL-QUR'AN
}

\author{
Mahbub Ghozali \\ UIN Sunan Kalijaga Yogyakarta \\ mahbub.ghozali@uin-suka.ac.id
}

\author{
Ali Usman \\ UIN Sunan Kalijaga Yogyakarta \\ ali.usman@uin-suka.ac.id
}

\begin{abstract}
The Rationality in interpretation that tends to be disputed can be used as an instrument to provide the contextual meaning of the Qur'an. Rationality equipped by science can actualize meanings that are more relevant to the development of society. The actual meaning has an impact on easier understanding for the community. This study aims to reveal the function of rationality in contextual interpretation without having to be fixated on the significance of a verse. This study uses primary data sources from Terjemah dan Tafsir al-Qur'an bahasa Arab dan Latin by Bachtiar Surin. This interpretation is used, aside from being abandoned by many researchers, it is also used as another way to actualizing meaning. This study uses a qualitative method with content analysis as a data analysis tool. This study finds the significance of rationality in interpretation through the inseparable relationship of reason with the Qur'an. Intellect as a gift from God can be used to explain God's language. In its application, Rationality can provide contextual meaning in two forms. First, the actualization of meaning with terms that are relevant to a modern context. Second, rationality functions as scientific reasoning to provide factual evidence for the meaning of the Qur'an. The actualizing of the Qur'an meaning can be achieved by rationality so that the contextual device in interpretation does not only emphasize significant meaning on the verse.
\end{abstract}

Keywords: bachtiar surin; contextual; rationality 


\begin{abstract}
Abstrak
Rasionalitas dalam penafsiran yang cenderung diperselisihkan dapat dijadikan sarana untuk memberikan pemahaman terhadap al-Qur'an secara kontekstual. Rasionalitas yang dilengkapi oleh ilmu pengetahuan dapat mereaktualisasi makna yang lebih relevan dengan perkembangan masyarakat. Pemaknaan secara aktual berdampak pada pemahaman yang lebih mudah kepada masyarakat. Penelitian ini bertujuan untuk mengungkapkan fungsi rasionalitas dalam penafsiran kontekstual tanpa harus terpaku dengan signifikansi pesan yang terkandung dalam sebuah ayat. Untuk mencapai tujuan tersebut, penelitian ini menggunakan sumber data primer dari Terjemah dan Tafsir al-Qur'an bahasa Arab dan Latin karya Bachtiar Surin. Tafsir ini digunakan, selain ditinggalkan oleh banyak peneliti juga didasarkan pada penggunaan cara lain dalam mengaktualisasi makna. Penelitian ini menggunakan metode kualitatif dengan content analysis sebagai perangkat analisa data. Penelitian ini menemukan signifikansi rasionalitas dalam penafsiran melalui hubungan akal dengan al-Qur'an yang tidak dapat dipisahkan. Akal sebagai anugerah Tuhan dapat digunakan untuk menjelaskan bahasa Tuhan. Dalam aplikasinya, akal dapat memberikan penafsiran secara kontekstual dalam dua bentuk. Pertama, reaktualisasi makna dengan istilah yang relevan dengan keilmuan modern. Kedua, rasionalitas berfungsi sebagai penalaran ilmiah dengan bentuk memberikan bukti faktual atas kebenaran kandungan makna al-Qur'an. Keberhasilan rasionalitas dalam mereaktualisasi makna dengan dua bentuk tersebut membuktikan bahwa penafsiran kontekstual dapat ditempuh dengan menggunakan rasionalitas yang bersifat subjektif, sehingga perangkat kontektulitas dalam penafsiran tidak hanya menekankan pada penemuan pesan makna sesuai dengan penggunaannya di masa al-Qur'an turun.
\end{abstract}

Kata Kunci: bachtiar surin; kontekstual; rasionalitas

\title{
Pendahuluan
}

Penafsiran kontekstual yang selama ini diupayakan dengan menemukan pesan utama ayat yang diaktualisasikan pada masa sekarang, ${ }^{1}$ dapat dilakukan dengan hanya mendasarkan pada pengetahuan subjektif penafsir. Semangat memperbaharui pesan

${ }^{1}$ Mohammed Arkoun, "The Notion of Revelation: From Ahl Al-Kitab to the Societies of the Book," Die Welt Des Islams 28, no. 1/4 (1988): 71, https://doi.org/10.2307/1571165. 
yang menjadi kerangka dasar penafsiran kontekstual ${ }^{2}$ dapat dicapai dengan memaksimalkan pengetahuan yang dimiliki oleh seorang mufassir dalam kerangka rasionalitasnya. Dengan penggunaan rasionalitas, pesan al-Qur'an akan lebih tersampaikan, karena makna yang dihasilkan berkesesuaian dengan realitas pengetahuan. Hal yang sama juga disampaikan oleh Khalāf Allah yang dikutip Rippin dengan menyebutkan bahwa pesan al-Qur'an dapat dengan mudah diterima jika penjelasannya menggunakan data sejarah yang kebenarannya sesuai dengan realitas yang diketahui masyarakat. ${ }^{3}$ Salah satu penafsir yang melakukan upaya semacam di Indonesia adalah Bachtiar Surin. Surin memberikan keleluasaan terhadap akal dalam menafsirkan al-Qur'an. ${ }^{4}$ Akal menjadi sarana dalam menafsirkan al-Qur'an yang relevan pemaknaannya dengan realitas kekinian.

Sejauh ini studi penafsiran yang dilakukan oleh Bachtiar Surin tidak banyak diminati oleh para pengkaji tafsir di Indonesia. Kajian yang ada cenderung menggunakan penafsiran Surin sebagai contoh dan penguat atas beragam argumentasi yang diberikan, sehingga nuansa penafsirannya tidak terekspos dalam kajian tersebut. $^{5}$ Sedangkan beberapa kajian lain hanya bersifat pengenalan terhadap upaya penafsiran yang dilakukan Surin. Federspiel sebagai tokoh awal yang mengkaji tafsir Indonesia hanya memberikan gambaran singkat tentang tujuan dan bentuk penerjemahan yang dilakukan oleh Surin sebagai representasi karya

2 Abdullah Saeed, Al-Qur'an Abad 21: Tafsir Kontekstual, trans. Ervan Nurtawab (Bandung: Mizan, 2016), 145.

3 Andrew Rippin, Muslims: Theor Religious Beliefs and Practices, vol. 2 (New York: Routledge, 1993), 107.

4 Bachtiar Surin, Terjemah \& Tafsir Al-Qur'an Huruf Arab \& Latin (Bandung: Penerbit Fa. Sumatra, 1978), 7.

5 Jauhar Azizy, Moh. Anwar Syarifuddin, and Hani Hilyati Ubaidah, "Thematic Presentations in Indonesian Qur'anic Commentaries," in Proceedings of the 1st International Conference on Recent Innovations - ICRI (Jakarta: Scitepress, 2020), 1962-69, https://doi.org/10.5220/0009937919621969; Rikho Afriyandi, "Analisis Ujaran Kebencian Dalam Bermedia Sosial: Kajian Atas Semangat Perdamaian Dalam Al-Quran," Journal of Islamic Civilization 3, no. 1 (April 30, 2021): 24-33, https://doi.org/10.33086/JIC.V3I1.1893.

TAJDID vol. 20, No. 2, Juli - Desember 2021 | 175 
terjemah di Indonesia. ${ }^{6}$ Bahkan, dalam kajian Gusmian, tafsir ini hanya disebut sebagai perwakilan bentuk tafsir pada periode 1970an hingga 1980-an. ${ }^{7}$ Hal yang tidak jauh berbeda juga dilakukan oleh Zuhdi dengan mencantumkan jenis tafsir ini sebagai bagian dari penafsiran pada abad ke-20 di Indonesia. ${ }^{8}$ Pengkajian terhadap Terjemah dan Tafsir al-Qur'an huruf Arab dan Latin karya Bachtiar Surin tidak pernah dilakukan secara mendalam sebelumnya. Narasi-narasi pemahaman Surin terhadap al-Qur'an yang bersifat praktis dan rasional belum pernah diungkapkan. Kajian yang dilakukan hanya berkisar pada penyebutan dan pengenalan atas keberadaan tafsir ini, tanpa memberikan penjelasan atas kontribusinya dalam kajian tafsir kontekstual.

Sejalan dengan ini, tulisan ini bertujuan untuk menunjukkan fungsi rasionalitas dalam penafsiran yang diberikan oleh Bactiar Surin dalam karyanya untuk menghasilkan makna yang lebih relevan dengan konteks kekinian. Penelitian ini menunjukkan dua bukti adanya penggunaan akal dalam penafsiran yang dilakukan Bachtiar Surin. Pertama, posisi rasionalitas dalam penafsiran. Untuk menguatkan bukti ini, penelitian ini menunjukkan pandangan Surin atas fungsi akal dalam penafsiran dan hubungannya dengan alQur'an. Kedua, dampak yang dihasilkan dalam penggunaan rasionalitas terhadap pemahaman ayat. Penjelasan aplikasi penafsiran dengan menggunakan akal dijelaskan dalam bagian ini dengan menyertakan model dan bentuk kontekstualitas yang dimaksudkan dalam memahami dan menafsirkan ayat. Dua bukti tersebut menjadi dasar penting untuk menunjukkan upaya Surin dalam menafsirkan al-Qur'an dengan menggunakan akal yang bertujuan mengkontekskan pesan al-Qur'an dalam kehidupan modern.

${ }^{6}$ Howard M. Federspiel, Kajian Al-Qur'an Di Indonesia: Dari Mabmud Yunus Hingga Qurasih Shihab, trans. Tajul Arifin (Bandung: Mizan, 1996).

7 Islah Gusmian, Khazanah Tafsir Indonesia, Dari Hermeneutika Hingga Ideologi (Yogyakarta: LKiS, 2013), 62.

${ }^{8}$ M. Nurdin Zuhdi, Pasaraya Tafsir Indonesia: Dari Kontestasi Metodologi Hingga Kontekstualisasi (Yogyakarta: Kaukaba, 2014), 73. 
Penelitian ini berangkat dari argumentasi bahwa penafsiran kontekstual dapat dilakukan dengan menggunakan sarana akal yang telah dilengkapi oleh ilmu pengetahuan. Keberadaan ilmu pengetahuan dapat menjadi sarana untuk memberikan penafsiran yang lebih kontekstual terhadap al-Qur'an. Hal yang sama juga dijelaskan oleh Abduh dengan penekanan pada pentingnya rasionalitas dalam menangkap kandungan wahyu. ${ }^{9}$ Realitas kontemporer yang berkembang karena perkembangan keilmuan menjadikan penafsiran al-Qur'an menjadi niscaya untuk menggunakan ilmu pengetahuan. Hal yang sama juga disebutkan Sahiron yang menekankan penafsiran al-Qur'an secara holistik dengan melibatkan perkembangan ilmu pengetahuan modern dalam menguatkan signifikansi fenomena dinamis. ${ }^{10}$ Arah baru dalam penafsiran al-Qur'an secara kontekstual dapat dilakukan dengan memberikan pemahaman atas narasi al-Qur'an dengan menggunakan akal yang dilengkapi dengan ilmu pengetahuan.

Kajian tentang rasionalitas dalam penafsiran yang dilakukan Surin sebagai upaya menerikan pemahaman al-Qur'an yang lebih kontekstual menggunakan metode kualitatif dengan jenis penelitian studi pustaka. Sumber data yang digunakan dalam penelitian ini diambil dari sumber data primer dan sumber data sekunder. Sumber data primer yang dimaksud dalam penelitian ini merupakan literatur pokok yang berkaitan langsung dengan objek penelitian, yakni Terjemah dan Tafsir al-Qur'an buruf Arab dan Latin karya Bachtiar Surin. Sedangkan sumber data sekunder merupakan data-data yang berkaitan dengan objek penelitian baik yang bersumber dari buku, hasil penelitian, maupun data-data lain yang relevan dengan penelitian ini. Sedangkan, dalam proses analisa data, penelitian ini menggunakan content analysis yang dapat

9 Aliaa Ibrahim Dakroury, "Toward a Philosophical Approach of the Hermeneutics of the Qur'an," American Journal of Islamic Social Sciences 23, no. 1 (2006): 24, https://doi.org/10.35632/ajiss.v23i1.433.

${ }^{10}$ Sahiron Syamsuddin, Pendekatan Ma Nā-Cum-Maghzā Atas Al-Qur'an Dan Hadis: Menjawab Problematika Sosial Keagamaan Di Era Kontemporer (Yogyakarta: Lembaga Ladang Kata, 2020). 
membantu peneliti untuk melakukan konseptualisasi atas narasinarasi kontekstual yang tersebar dalam beberapa penafsiran ayat untuk kemudian dilakukan generalisasi agar terbentuk satu konsep utuh tentang fungsi rasionalitas dalam penafsiran ayat. Sedangkan proses pengambilan data dalam penelitian ini menempuh tiga langkah, yakni pengumpulan data, reduksi data, dan penarikan kesimpulan. $^{11}$

\section{Posisi Logika dalam Kajian Tafsir}

Rasionalitas dalam penafsiran memiliki kecenderungan pemaknaan yang berbeda. Rasionalitas dalam penafsiran dapat bermakna proses berpikir yang tidak didahului penghayatan (tadbir) dan perenungan (tafkir). ${ }^{12} \mathrm{Hal}$ yang sama juga disebutkan oleh alBiqā' yang menyatakan bahwa rasionalitas dalam penafsiran merupakan perkataan yang tidak didasarkan pada ilmu. ${ }^{13}$ Pendapat lain disebutkan oleh al-Zurqāin̄i yang menyatakan bahwa yang dimaksud rasionalitas adalah ijtihad, sehingga ia berpotensi untuk sesuai dengan teks-teks yang memiliki argumentasi jelas. ${ }^{14}$ Rasionalitas dalam pengertian ini diperbolehkan untuk digunakan dalam penafsiran al-Qur'an karena berlandaskan pada aspek-aspek keilmuan yang dibutuhkan dalam memahmi al-Qur'an. ${ }^{15}$ Sedangkan rasionalitas yang dilarang dalam penafsiran dimaksudkan oleh alShuyutī sebagai hawa nafsu. ${ }^{16}$ Pemaknaan yang berbeda dalam memahami rasionalitas berdampak pada perdebatan penggunaannya dalam penafsiran.

${ }^{11}$ Matthew B. Miles and A. Michael Huberman, Qualitative Data Analysis (a Source Book of New Methods) (Beverly Hills: SAGE Publications, 1984).

12 Abū Manşūr Al-Azharī, Ma'anì al-Qirāàt li al-Ažharì, vol. 2 (Saudi Arabia: Jāmi'ah al-Mulk Su'ūd, 1991), 46.

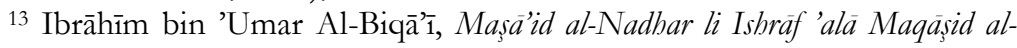
Siwar, vol. 1 (Riyād': Maktabah al-Ma'ārif, 1987), 441.

14 Muhammad 'Abd al-'Ażīm Al-Zurqānī, Manāhil al-'Irfān, vol. 2 (Beirut: Dār al-Fikr, 1988), 49.

15 Muhammad Ĥusayn Al-Dhahabī, al-Tafsìr wa al-Mufassirūn, vol. 1 (Kairo: Maktabah Wahbah, 2007), 183.

${ }^{16}$ Jalāl al-Dīn Al-Suyūțī, al-Itqān fi 'Ulūm al-Qur'an, vol. 4 (Beirut: al-Hay'ah al-Mişriyah al-'Ammah li al-Kitāb, 1974), 212.

178 | TAJDID vol. 20, No. 2, Juli - Desember 2021 
Problematika penggunaan akal dalam menafsirkan al-Qur'an cenderung banyak diperdebatkan. Akal dianggap sebagai komponen terlarang dalam menafsirkan al-Qur'an. ${ }^{17}$ Landasan pelarangan tersebut didasarkan pada potensi akal terhadap kesalahan, karena sifatnya yang praduga $($ dzan $) .{ }^{18}$ Potensi kesalahan dalam memahami al-Qur'an dengan menggunakan akal terbatas pada akal yang tidak dilengkapi dengan ilmu pengetahuan. ${ }^{19} \mathrm{Hal}$ yang sama juga disebutkan oleh Ibn Taymiyah yang pada awalnya melakukan pelarangan terhadap tafsir dengan menggunakan rasio. Menurutnya, penafsiran dengan menggunakan akal yang dilarang dibatasi bagi akal yang tidak memiliki ilmu. ${ }^{20}$ Dikotomi antara akal yang berilmu dan tidak berilmu dielaborasi oleh al-Dhahabī dengan membuat kriteria penafsiran dengan menggunakan akal dengan istilah al-tafsìr bi al-ra'y al-jä'iz dan al-tafsìr bi al-ra'y al-madhmüm. ${ }^{21}$ Perdebatan dalam penggunaan akal dalam penafsiran hanya dibatasi pada penggunaan akal tanpa didasarkan pada ilmu.

\section{Ragam Pembacaan Kontekstual dalam Tafsir al-Qur'an}

Keberadaan tafsir kontekstual tidak dapat dilepaskan dari situasi yang tidak mampu dijawab dengan menggunakan pendekatan tekstual. Keterbatasan pemahaman tekstual dalam melihat realitas yang berkembang menjadi pemicu kemunculan pendekatan kontekstual. ${ }^{22}$ Orientasi pendekatan ini yang melihat perkembangan konteks dalam memahami al-Qur'an dengan merelevansikan perkembangan maknanya pada konteks kekinian menjadikan pendekatan ini mampu memberikan solusi atas

17 Ibn Taymiyah, Muqaddimah fi Uşul al-Tafsìr (Beirut: Dār Maktabah alĤayāh, 1980), 46.

18 Al-Dhahabī, al-Tafsì wa al-Mufassirūn, 1:183.

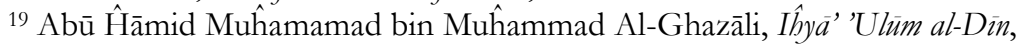
vol. 3 (Beirut: Dār al-Ma'rifah, n.d.), 127.

20 Taymiyah, Muqaddimah fi Usul al-Tafsir, 31-32.

${ }^{21}$ Al-Dhahabī, al-Tafsì wa al-Mufassirūn.

22 Saeed, Al-Qur'an Abad 21: Tafsir Kontekstual, 12.

TAJDID vol. 20, No. 2, Juli - Desember 2021 | 179 
problem yang dihadapi masyarakat secara aktual. ${ }^{23}$ Dengan pembacaan terhadap al-Qur'an melalui pendekatan ini dapat membuktikan kesesuaian kandungan al-Qur'an yang tidak terbatas zaman dan tempat. ${ }^{24}$ Dasar dari konsep ini diklaim bersumber dari praktik penafsiran yang telah dilakukan oleh 'Umar bin alKhattāb, ${ }^{25}$ sehingga secara substantif model penafsiran ini tidak bertentangan dengan prinsip-prinsip dalam kajian al-Qur'an. ${ }^{26}$ Kebutuhan terhadap interpretasi al-Qur'an dengan mengacu pada aspek pragmatisnya telah mengembangkan kajian al-Qur'an pada dimensi kontekstualnya.

Perkembangan kajian tafsir kontekstual dibuktikan dengan kelahiran beragam cara untuk menafsirkan al-Qur'an melalui analisa terhadap konteksnya. Semenjak kajian ini dikenalkan pada akhir abad ke-20, beragam pandangan dan teori mulai bermunculan, baik secara konsep ataupun dalam bentuk metode yang lebih praktis. Secara konsep, tawaran untuk memberikan pemahaman atas al-Qur'an dengan berdasarkan pada konteks dilandasi keyakinan bahwa al-Qur'an merujuk pada konteks aktual. $^{27}$ Sedangkan secara metodis, pendekatan kontekstual diproduksi dengan metode yang aplikatif dengan beragam sebutan, seperti Rahman menyebutnya dengan double movement, ${ }^{28}$ Esack

${ }^{23}$ M Solahudin, "Pendekatan Tekstual Dan Kontekstual Dalam Penafsiran Alquran," Al-Bayan: Jurnal Studi Ilmu Al- Qur'an Dan Tafsir 1, no. 2 (December 30, 2016): 115-30, https://doi.org/10.15575/al-bayan.v1i2.1596.

${ }^{24}$ Abad Badruzaman, "Toward an Indonesian Current in Islamic Exegesis: An Attempt to Contextualize the Maqasid Al-Quran," Journal of Indonesian Islam, 2019, https://doi.org/10.15642/JIIS.2019.13.2.505-524.

${ }^{25}$ M. Ulil Abshor, "Pendekatan Kontekstualis Dalam Penafsiran Al-Qur'an (The Study Of Abdullah Saeed's Qur'anic Interpretation)," Al-Adabiya: Jurnal Kebudayaan Dan Keagamaan, 2018, https://doi.org/10.37680/adabiya.v13i02.25.

${ }^{26}$ Saeed, Al-Qur'an Abad 21: Tafsir Kontekstual, 13.

27 Muhammad Daud Rahbar, "The Challenge of Modern Ideas and Social Values to Muslim Society," The Muslim World 48, no. 4 (October 1958): 274-85, https://doi.org/10.1111/j.1478-1913.1958.tb02579.x.

28 Fazlur Rahman, Islam and Modernity: Transformation of an Intellectual Tradition (Chicago: University of Chicago Press, 1979), 6-7.

180 | TAJDID vol. 20, No. 2, Juli - Desember 2021 
mengkonsepnya dalam gagasan hermeneutika pembebasan, ${ }^{29}$ Saeed memberikan gagasan dalam konsep nilai etis, ${ }^{30}$ dan Sahiron mengenalkan dengan sebutan ma'na-cum-maghza. ${ }^{31}$ Beragam jenis metode yang dikembangkan dalam kajian tafsir kontekstual sebagai upaya menjembatani problem yang tidak dapat diselesaikan oleh tafsir tekstual.

\section{Pengenalan terhadap Terjemah dan Tafsir al-Qur'an Karya Bachtiar Surin}

Terjemah dan Tafsir al-Qur'an yang disusun oleh Bachtiar Surin dimulai sejak tahun 1973 hingga selesai sekitar tahun 1976. Kehadirannya ditujukan untuk meningkatkan kajian al-Qur'an pada level yang lebih tinggi lagi. Peningkatan atas pengembangan alQur'an dibutuhkan agar dapat memberikan tuntunan kepada umat manusia dalam menjalani kehidupan pribadi, keluarga, masyarakat, bahkan kehidupan bernegara. Meskipun dalam pengakuan Bahar Surin, sebagai direktur Firma Sumatra sebagai penerbit tafsir ini, kemajuan pengkajian al-Qur'an di Indonesia pada masa itu telah sampai pada fase pengertian dan penghayatan. Untuk mencapai tingkatan selanjutnya, pemahaman atas al-Qur'an haruslah didasarkan pada pemahaman yang rasional, sehingga kandungan mukjizatnya dapat diterima oleh akal. ${ }^{32}$ Tujuan ini akan memberikan pengaruh terhadap narasi yang diberikan dalam melakukan penerjemahan maupun penafsiran dalam karya tersebut.

Tujuan untuk memberikan kemudahan pemahaman agar dapat diimplementasikan dalam kehidupan berdampak pada struktur penjelasan yang mudah dipahami. Dalam konteks ini, Federspiel memberikan analisa terhadap struktur yang digunakan

29 Farid Esack, Quran, Leberation and Pluralism: An Islamic Perspective of Interreligious Solidarity Againt Oppression (London: Oneworld Publication, 1997).

30 Saeed, Al-Qur'an Abad 21: Tafsir Kontekstual.

31 Sahiron Syamsuddin, "Ma'Na-Cum-Maghza Approach To The Qur'an: Interpretation Of Q. 5:51," in International Conference on Qur'an and Hadith Studies (ICQHS 2017), vol. 137 (Atlantis Press, 2018), 131-36.

32 Surin, Terjemah \& Tafsir Al-Qur'an Huruf Arab \& Latin, xiv-xv.

TAJDID vol. 20, No. 2, Juli - Desember 2021 | 181 
dalam Terjemah dan Tafsir al-Qur'an. Menurutnya, Surin memberikan penekanan terhadap aspek transletrasi Arab ke dalam bahasa Indonesia. Langkah ini bertujuan untuk memudahkan masyarakat yang tidak dapat membaca aksara Arab agar dapat dengan mudah membaca al-Qur'an melalui aspek transletrasinya. ${ }^{33}$ Sedangkan dalam aspek penerjemahan, Surin dalam pandangan Federspiel menempuh cara memberikan penjelasan terhadap kata-kata tertentu yang dianggap sulit untuk dipahami. Dalam proses penerjemahan tersebut, Surin juga menyisipkan penjelasan yang lebih atas kandungan makna kata yang diterjemahkan agar dapat memberikan penekanan pemahaman. ${ }^{34}$ Sisipan penjelasan dalam proses penerjemahan ini yang dimaksudkan dalam karya ini sebagai penafsiran, sehingga karya yang dihasilkan oleh Surin disebut dengan terjemah sekaligus penfsiran.

\section{Rasionalitas al-Qur'an dalam Pandangan Bachtiar Surin: Akal sebagai Sarana Kontekstualitas Pemahaman}

Pemahaman atas kontekstualitas pemaknaan ayat bersumber dari pemahaman atas kebutuhan makna yang berkembang dengan menyesuaikan perkembangan tempat dan waktu. Surin memberikan dasar argumentasi atas kontekstualitas makna dengan menggunakan Q.S. al-Baqarah [2]: 106. Ia menjelaskan,

Hukum Quraniyah diturunkan untuk mengatur perkembangan psychis dan perkembangan perbuatan, tindakan, dan tingkah laku manusia yang dalam kenyataan bahwanya mempunyai kebebasan untuk bertindak, baik psychis maupun phisik. Lagi pula dalam kebebasan itu tidak ada serba ketentuan (determinisme) ke arah mana jurusannya, disamping ia dapat berubah menurut perubahan waktu, tempat, dan keadaan. Karena itu harus ada hukum yang mengatur perkembangannya. Hukum mana dapat pula

${ }_{33}$ Federspiel, Kajian Al-Qur'an Di Indonesia: Dari Mabmud Yunus Hingga Qurasib Shibab, 154.

${ }^{34}$ Federspiel, 155.

182 | TAJDID vol. 20, No. 2, Juli - Desember 2021 
berubah sesuai dengan perubahan perkembangan psichis dan phisik manusia sendiri.

Determinisme agama dalam pandangan Surin berasal dari Allah melalui petunjuk dengan hidayah yang diberikan kepada manusia berupa akal dan agama. ${ }^{36}$ Kebutuhan atas perubahan diperoleh dari pancaran cahaya ketuhanan pada akalnya, sehingga mampu memberikan kesesuaian atas perubahan konteks sosial dengan perubahan hukum. ${ }^{37}$ Akal memberikan jalan keluar bagi manusia untuk memahami narasi-narasi keagamaan untuk direaktualisasi kandungannya.

Kesadaran atas fungsi akal dalam agama dapat memberikan jalan untuk lebih memahami al-Qur'an secara komprehensif. Surin mendefinisikan akal sebagai modal fitrah manusia yang dapat dipergunakan untuk mendapatkan petunjuk Tuhan. ${ }^{38}$ Pemanfaatan modal yang tidak benar akan berdampak pada kesalahan dalam memahami narasi agama. Dalam hal ini, Surin menggambarkan hubungan akal dan agama sebagai modal dan laba dalam pemahaman atas Q.S. al-Baqarah [2]: 16. Tindakan merusak dan memutuskan hubungan antara akal dan agama, dapat menyebabkan kerusakan pemahaman atas konsep agama. Ia menjelaskannya dalam memahami wa yaqta'ūn mà amar Allah bih an yushala (memutuskan apa yang diperintahkan Allah untuk disambungkan) dalam Q.S. al-Baqarah [2]: 27 dengan makna merusak dan memutuskan kelestarian antara akal dan ajaran agama. ${ }^{39}$ Akal menjadi sarana yang dapat menguraikan petunjuk Tuhan yang terdapat dalam al-Qur'an, sehingga memaksimalkan akal dalam agama berarti memaksimalkan modal dalam memperoleh laba.

${ }^{35}$ Surin, Terjemah \& Tafsir Al-Qur'an Huruf Arab \& Latin, 33.

${ }^{36}$ Surin, 87.

${ }^{37}$ Surin, 87.

${ }^{38}$ Surin, 7.

${ }^{39}$ Surin, 11.

TAJDID vol. 20, No. 2, Juli - Desember 2021 | 183 
Pemanfaatan akal dalam penafsiran terwujud dalam penggunaan ilmu pengetahuan ilmiah sebagai bentuk penalaran dalam memahami al-Qur'an. Surin mereaktualisasi makna ba'udah (nyamuk) dalam Q.S. al-Baqarah [2]: 26 dengan makhluk yang lebih kecil darinya, yakni kuman. Seseorang yang menggunakan akalnya dapat mengetahui jenis kuman yang berbahaya bagi manusia. Perumpamaan Tuhan dalam ayat ini justru tidak menjadikan-Nya malu, akan tetapi dapat dimanfaatkan sebagai sarana penyelidikan ilmiah. ${ }^{40}$ Penyelidikan secara ilmiah dengan menggunakan akal dapat mengungkapkan kebenaran kandungan al-Qur'an secara empiris ${ }^{41}$ dan secara historis. ${ }^{42}$ Secara empiris, Surin menyebutkan makna ayat wa arshuh 'alā al-mā' (dan Arsy-Nya dari air) dalam Q.S Hūd [11] tentang penciptaan sebagai dasar dari teori yang menyebutkan bahwa asal kejadian kehidupan semesta berasal dari air. ${ }^{43}$ Sedangkan secara historis, makna dari wa ista'marakum fiha dalam Q.S Hūd [11]: 61 dimaknai Surin dengan "lalu dijadikannya kamu makhluk berbudaya di atasnya". ${ }^{44}$ Kebudayaan yang dicapai oleh bangsa 'Ad yang disebutkan dalam ayat tersebut menurut Surin telah terbukti secara historis dengan ditemukan peradaban yang tinggi dengan ditemukan alat-alat pertanian dan teknik bangunan. ${ }^{45}$ Penemuan atas bukti-bukti tersebut dicapai dengan penggunaan akal sebagai sarana dalam memahami al-Qur'an.

Peletakan akal sebagai sarana memahami al-Qur'an memberikan signifikansi terhadap peran pembuktian ilmiah atas narasi-narasi yang terkandung dalam suatu ayat. Ia memberikan kriteria dalam pengambilan keputusan yang benar untuk mencari hikmah dan penetapan hukum yang dikehendaki oleh Allah dalam al-Qur'an. Fungsinya sebagai alat berpikir dan sarana dalam

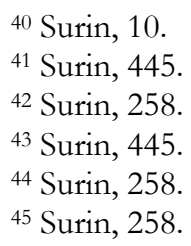


menetapkan kesimpulan ${ }^{46}$ berdampak pada pengembangan pemahaman al-Qur'an yang lebih saintifik. ${ }^{47}$ Langkah ini dilakukan oleh Surin untuk memberikan pemahaman terhadap ayat yang lebih kontekstual dan mengikuti term yang dikenal oleh masyarakat modern. Pemberian konteks makna yang setara dengan capaian bahasa pembacanya dapat memberikan pemahaman yang lebih mudah dan gampang untuk dimengerti. ${ }^{48}$ Bahkan, upaya untuk menyinergikan akal dan agama yang dilakukan oleh Surin memberikan dampak pada penjagaan pemahaman atas agama. ${ }^{49}$ Hal yang sama juga disebutkan oleh Waseem dan Hafeez yang menyebutkan sinergitas agama dan akal membawa dampak pada terciptanya kedamaian dan keharmonisan..$^{50}$

\section{Dampak Rasionalitas dalam al-Qur'an: Redefinisi dan Aktualisasi}

Perkembangan metode penalaran ilmiah termanifestasi dalam wujud kemajuan pencapaian ilmu pengetahuan modern. Surin menggunakan perkembangan penalaran dalam memahami alQur'an dalam dua bentuk. Pertama, redefinisi makna kata dan konsep yang relevan dengan istilah ilmu pengetahuan. Bentuk ini hampir menjiwai penerjemahan dan penafsiran Surin atas kata-kata

46 Abdul Kadir, "Genetika Dalam Perspektif Al-Quran Studi Analisis Perbandingan Penafsiran Ayat Genetika Kecerdasan Dan Konsep STIFIn" (Pascasarjana Institut Ilmu Al-Qur'an (IIQ) Jakarta, 2019), http://repository.iiq.ac.id//handle/123456789/201.

47 Mochammad Arifin, "Epistemologi Rasionalisme Rene Descartes Dan Relevansinya Terhadap Penafsiran Al-Qur'an," Jurnal Ilmiah Ilmu Ushuluddin 17, no. 2 (December 1, 2018): 147-57, https://doi.org/10.18592/JIU.V17I2.2240.

48 Rian Ardiansyah, "Konsep Akal Dalam Tafsir Al-Misbah" (UIN Raden Intan Lampung, 2018).

${ }^{49}$ Surin, Terjemah \& Tafsir Al-Qur'an Huruf Arab \& Latin, 11.

${ }^{50}$ Waseem Khan and Hafeez Ullah Khan, "The Gulen Movement: The Blending of Religion and Rationality," Journal of Research in Social Sciences (JRSS) 6, no. 1 (January 2018); Sukino Sukino, Wahab Wahab, and Ahmad Fauzi Murliji, "Development and Contextualization of Multicultural Insight-Based Quran Hadith Materials in Madrasah Aliyah," Edukasia : Jurnal Penelitian Pendidikan Islam 15, no. 2 (August 30, 2020): 293-314, https://doi.org/10.21043/EDUKASIA.V15I2.8045.

TAJDID vol. 20, No. 2, Juli - Desember 2021 | 185 
dalam al-Qur'an. Ia memaknai faddaltukum dalam Q.S. al-Baqarah [2]: 47 yang merujuk pada bani Israil sebagai keutamaan dibidang agama dan kebudayaan, ${ }^{51}$ in yakun ghaniyan aw faqiran fa awla bibima dalam Q.S. al-Nisā' [4]: 135 dengan hak asasi manusia, ${ }^{52}$ biafwabibim dalam Q.S. Bara'ah [9]: 32 dengan propaganda-propaganda dalam segala bentuk, ${ }^{53}$ dan dif'un dalam al-Nahl [16]: 5 dengan wool. ${ }^{54}$ Penerjemahan ulang atas makna yang lebih relevan dengan perkembangan budaya akan lebih memudahkan masyarakat dalam memahami al-Qur'an.

Perkembangan bahasa memiliki relevansi dengan perkembangan konsep yang terkandung dalam satu istilah bahasa. Upaya menjembatani konsep makna dari bahasa yang digunakan dalam al-Qur'an dengan istilah dalam bahasa lain yang telah berkembang juga menjadi perhatian dalam narasi tafsir. Surin memberikan redefinisi secara konsep terhadap beberapa kata yang disesuaikan dengan perkembangan ilmu pengetahuan modern, seperti wa ibyaddad 'aynuh dalam Q.S Yusuf [12]: 84 dengan penjelasan rabun dan penyebabnya dalam ilmu kedokteran. ${ }^{55}$ Menurut Surin, penyakit yang diderita Ya'qub disebabkan terlalu lama menahan dukacita, amarah, rindu yang dapat menimbulkan radang urat saraf penglihatan (neuritis optica). ${ }^{56}$ Hal yang sama juga dilakukan Surin dalam menjelaskan fafataqnahuma dalam Q.S. alAnbiyā' [21]: 30 dengan penjelasan,

Maksudnya, matahari adalah benda angkasa yang bernyalanyala yang telah berputar keliling sumbu sejak berjuta-juta tahun. Dalam proses perputarannya dengan kecepatan tinggi itu, maka terpelantinglah bingkahan-bingkahan yang

\footnotetext{
${ }^{51}$ Surin, Terjemah \& Tafsir Al-Qur'an Huruf Arab \& Latin, 16.

52 Surin, 201.

53 Surin, 386.

54 Surin, 557.

${ }^{55}$ Surin, 496.

56 Surin, 496.
} 
akhirnya menjadi bumi dan beberapa benda angkasa lainnya dari bingkah matahari itu. ${ }^{57}$

Redefinisi atas konsep bahasa sebagai bagian dari capaian akal dalam memajukan ilmu pengetahuan menjadi landasan dasar untuk memahami makna ayat dengan menggunakan istilah modern, sehingga fungsinya dapat mengaktualisasi makna yang terkandung dalam al-Qur'an.

Kedua, pemahaman atas al-Qur'an dengan menggunakan metode analisis modern. Surin menggunakan metode intertektualis dalam memahami ayat yang jarang ditemukan dalam penafsiran Indonesia lainnya. Ia menafsirkan ayat-ayat yang berkaitan dengan cerita nabi-nabi dengan melakukan cross-check dengan narasi yang terdapat dalam kitab agama lain, misalnya dalam memahami ucapan Daud, kisah Isa, dan cerita Yusuf dengan menggunakan Injil. ${ }^{58}$ Selain itu, penjelasan terhadap makna Harut dan Marut dalam Q.S. al-Baqarah [2]: 102 dikorelasikan dengan kajian antropologi bahasa dalam mengidentifikasi Harut dan Marut sebagai malaikat atau jenis makhluk lainnya. Hal demikian, dalam pandangan Surin dibutuhkan untuk mendekatkan pemahaman dengan menggunakan kebiasaan masyarakat. Dalam konteks ini, keserupaan Harut dan Marut ditunjukkan dengan contoh kebiasaan masyarakat Indonesia dalam melihat orang yang cerdas dengan menggunakan pakaian perlente sebagai Raden. Meskipun pada hakikatnya orang tersebut bukanlah keturunan bangsawan, tetapi sebutan tersebut hanya didasarkan penampakan yang sama. ${ }^{59}$ Konsep feminisme juga menjadi pertimbangan Surin dalam menafsirkan Q.S. Ali Imran [3]: 195. Ia memandang ayat ini sebagai landasan untuk persamaan hak dan kewajiban laki-laki dan perempuan. Ia menyebutkan bahwa laki-laki dan perempuan memiliki kedudukan yang sama dalam bidang kemanusiaan, yang

\footnotetext{
${ }^{57}$ Surin, 692.

58 Surin, 243; 474.

${ }^{59}$ Surin, 31 .
} 
membedakan keduanya adalah amal perbuatannya. ${ }^{60}$ Narasi penjelasan atas makna al-Qur'an dengan memanfaatkan produk keilmuan modern berfungsi untuk mempermudah pemahaman terhadap al-Qur'an.

Relasi makna modern dan penggunaan analisa dengan menggunakan keilmuan modern berdampak pada aktualisasi makna al-Qur'an. Kandungan makna yang dikehendaki menjadi lebih relevan untuk memberikan tuntunan dalam mengatasi problem-problem aktual masyarakat, ${ }^{61}$ seperti feminisme, inter-faith, dan gap makna. Penelusuran kandungan makna dengan menggunakan pendekatan saintifik juga berdampak pada pengungkapan kandungan sains yang mendorong kemunculan penelitian-penelitian baru yang mengambil semangat al-Qur'an. ${ }^{62}$ Sedangkan Faraz dan Asiya memperluas cakupan fungsi sains dalam pemahaman al-Qur'an untuk mempermudah mengaplikasikan kandungannya dalam praktik kehidupan masyarakat muslim. ${ }^{63}$ Penemuan aspek baru dalam penafsiran dengan pendekatan yang lebih ilmiah dibutuhkan untuk menjaga relevansi makna al-Qur'an dengan perkembangan kehidupan masyarakat modern. Relevansi makna terhadap konteks menjadikan upaya Surin sebagai bagian dari perwujudan penafsiran kontekstual dengan wajah yang berbeda.

${ }^{60}$ Surin, 155.

${ }^{61}$ Jeppe Fuglsang Larsen, "Reinstating and Contextualizing Religion in the Analysis of Islamist Radicalization in the West," Distinktion: Journal of Social $\begin{array}{lllll}\text { Theory 22, no. } 2021) \text { 192-209, } & \end{array}$ https://doi.org/10.1080/1600910X.2021.1885050.

${ }^{62}$ Muqowim and Zulkipli Lessy, "Augmenting Science in the Islamic Contemporary World: A Strategic Attempt at Reconstructing the Future," AlJami'ab: Journal of Islamic Studies 57, no. 1 (June 29, 2019): 197-230, https://doi.org/10.14421/AJIS.2019.571.197-230.

63 Muhammad Samiullah Faraz and Syeda Asiya, "Impact of the Contextual Approach on the Qur'ānic Interpretations: An Analytical Study," Jihat Ul Islam 14, no. 1 (December 27, 2020): 1-20, https://doi.org/10.51506/JIHAT-UL-ISLAM.V14I1.167. 


\section{Wajah Baru Kontekstualitas al-Qur'an: Pemaksimalan Fungsi Rasio dalam Penafsiran}

Pemahaman terhadap kriteria tafsir kontekstual yang hanya dapat dilakukan dengan penekanan atas relevansi makna dengan konteks tidak dapat sepenuhnya diimplementasikan. Hasil penelitian ini justru menunjukkan pemaknaan secara kontekstual terhadap ayat dapat dilakukan dengan hanya menggunakan potensi rasio, tanpa harus berpedoman pada perubahan makna yang disebabkan perubahan konteks. Rasionalitas sebagai potensi yang diberikan oleh Tuhan secara alamiah (fitrah) dapat diaktifkan dengan memberikan asupan ilmu pengetahuan aktual. Rasionalitas yang telah diaktifkan akan dapat menangkap pemahaman terhadap narasi-narasi al-Qur'an yang relevan dengan kondisi masyarakat dan perkembangan keilmuan modern. Pengabaian terhadap potensi rasionalitas dalam memahami al-Qur'an, diibaratkan oleh Surin dengan kegagalan pedagang yang memiliki modal besar tetapi tidak mendapatkan keuntungan yang besar pula. Rasionalitas sebagai modal yang telah diberikan Tuhan kepada manusia dapat digunakan untuk memperoleh pemahaman atas al-Qur'an yang juga berasal dari Tuhan secara kontektual.

Penggunaan rasionalitas sebagai perangkat dalam memahami al-Qur'an secara kontekstual dilakukan dengan beragam bentuk. Surin memberikan dua bentuk cara sebagai implementasi pemahaman atas al-Qur'an dengan menggunakan rasio. Pertama, elaborasi makna kata sesuai dengan istilah yang digunakan dalam ilmu pengetahuan modern. Redefinisi atas makna kata dilakukan untuk menjaga signifikansi makna yang dimaksudkan dalam alQur'an dengan konteks masyarakat modern. Kedua, memasukkan logika modern dalam menafsirkan al-Qur'an. Penggunaan logika modern dalam penafsiran Surin terwujud dalam penggunaan keilmuan modern untuk memberikan perspektif baru dalam memahami al-Qur'an agar lebih relevan dengan konteks kekinian. Penggunaan intertekstual, analisis feminis, dan pendekatan 
antropologis mewarnai dalam beberapa penafsiran yang terdapat dalam terjemah dan Tafsir Qur'an dalam bahasa Arab dan Latin. Wujud kontekstualitas dalam pemahaman dan penafsiran yang digunakan Surin merupakan implementasi dari rasionalitas sebagai perangkat penafsiran secara kontekstual.

Penekanan rasionalitas sebagai perangkat dalam memahami al-Qur'an secara kontekstual merupakan dampak dari metode tafsir kontekstual yang hanya didominasi oleh objektivitas atas pemaknaan ayat yang dilakukan secara progresif. Sisi subjektivitas dalam metode ini disingkirkan dengan hanya terfokus pada kandungan makna ayat yang direlevansikan dengan konteks aktual. Menggunakan rasio dalam penafsiran justru memberikan ruang terbuka pada subjektivitas penafsir untuk memaknai al-Qur'an sesuai dengan masanya. Hal yang sama juga disebutkan Sahiron dengan menyebut langkah ini sebagai aliran subjektif yang berkeyakinan bahwa setiap penafsir memiliki nilai subjektifnya sendiri untuk memberikan pemahaman atas al-Qur'an sesuai dengan masanya. ${ }^{64}$ Penguasaan atas perangkat keilmuan modern untuk mereaktualisasi pemaknaan dapat dilakukan pada model penafsiran yang tidak membutuhkan penjelasan yang panjang dan mendalam. Tafsir dengan model ini dapat memberikan pemahaman terhadap kata-kata tertentu dalam sebuah ayat untuk dilakukan reaktualisasi makna atau menguatkan pemahamannya dengan menggunakan perangkat keilmuan modern tanpa kehilangan makna aslinya. ${ }^{65}$ Tujuan inilah yang dimaksudkan oleh Rosyada yang menyebutkan bahwa penjelasan dengan menggunakan perangkat keilmuan modern bertujuan untuk memberikan penekanan pemahaman. ${ }^{66}$ Kecenderungan Surin

64 Sahiron Syamsuddin, Hermeneutika Dan Pengembangan Ulumul Quran (Yogyakarta: Pesantren Newesea Press, 2017), 54.

${ }^{65}$ Matt Sheedy, "Habermas, Islam, and Theorizing the 'Other':," Critical Research on Religion 6, no. 3 (October 14, 2018): 331-50, https://doi.org/10.1177/2050303218800377.

${ }^{66}$ Dede Rosyada, “A Contextual Method of Interpreting the Qur'an: A Search for The Compatibility of Islam and Modernity," in Proceedings of the 
dalam melakukan penafsiran melakukan penekanan terhadap makna kata agar dengan penekanan terhadap transletrasi bertujuan untuk memberikan kemudahan bagi para pembacanya. Dengan model penafsiran kontekstual yang demikian dapat memberikan landasan bagi penggunaan akal dalam memahami al-Qur'an yang cenderung diperdebatkan.

Kebutuhan menempatkan rasionalitas dalam penafsiran disebabkan oleh perdebatan perangkat ini untuk digunakan dalam proses pemahaman al-Qur'an. Rasionalitas yang dianggap berawal dari praduga dan hawa nafsu berdampak pada pemahaman atas pesan kandungan al-Qur'an menjadi tidak benar. Akan tetapi, rasionalitas yang dimaksudkan dalam penelitian ini merupakan rasionalitas yang dilengkapi dengan ilmu pengetahuan, sehingga pemaknaan atas al-Qur'an menjadi relevan dengan perkembangan ilmu pengetahuan. Hal yang sama dijelaskan oleh al-Ghazālī yang menyebutkan bahwa pemahaman atas al-Qur'an tanpa menggunakan akal yang dilengkapi pengetahuan akan sulit terjadi. ${ }^{67}$ Bahkan, rasionalitas dalam Islam menjadi konsep penting dalam segala aspek pemahaman. ${ }^{68}$ Pandangan ini juga dikuatkan oleh Ibn Taymiyah yang menyebutkan bahwa akal yang dilengkapi ilmu pengetahuan dapat dijadikan sarana dalam memahami al-Qur'an. ${ }^{69}$ Penekanan atas fungsi rasionalitas dalam memahami al-Qur'an dengan wujud pemahaman yang lebih kontekstual dapat menguatkan kriteria bentuk rasionalitas yang dapat digunakan dalam penafsiran.

International Conference on Qur'an and Hadith Studies (ICQHS) (Atlantis Press, 2017), 1-6, https://doi.org/10.2991/ICQHS-17.2018.1.

${ }^{67}$ Al-Ghazāli, Ihyyā' 'Ulüm al-Dìn, 3:127.

68 Ayman Reda, "Islam, Rationality, and Self-Interest," Prophecy, Piety, and Profits, 2018, 303-35, https://doi.org/10.1057/978-1-137-56825-0_21; Diwan Taskheer Khan, "Mutazilaism: An Introduction to Rationality in Islam," International Journal of Engineering and Applied Sciences 4, no. 10 (2017): 257359, https://doi.org/10.0/CSS/ALL.CSS.

69 Taymiyah, Muqaddimah fi Usul al-Tafsìr, 31-32.

TAJDID vol. 20, No. 2, Juli - Desember 2021 | 191 
Produksi tafsir dengan menggunakan rasionalitas sebagai sumber dari pemaknaan kontekstual berdampak pada pemahaman yang lebih mudah ditangkap oleh akal. Relasi makna ayat yang dikuatkan dengan pembuktian empiris yang dilakukan oleh Surin terhadap ayat-ayat yang bernuansa sejarah dapat menegaskan kebenaran atas narasi tersebut. ${ }^{70} \mathrm{Hal}$ yang sama juga dilakukan ketika menafsirkan makna ayat yang berkaitan dengan mu'jizat alQur'an. ${ }^{71}$ Pembuktian mu'jizat al-Qur'an secara ilmiah berdampak pada pengertian i'jaz yang lebih mudah dipahami oleh masyarakat awam sekalipun. Hal yang sama disebutkan oleh al-Najjār yang mengatakan bahwa pembuktian kemu'jizatan al-Qur'an secara ilmiah dapat menguatkan kebenaran atas kandungannya. ${ }^{72} \mathrm{Hal}$ ini juga akan memberikan pemahaman yang mudah kepada masyarakat dengan menyesuaikan makna ayat dengan pemahaman masyarakat di suatu tempat dan masa yang menjadi bukti bahwa model penafsiran yang dilakukan Surin sebagai bagian dari metode tafsir kontekstual. Tujuan yang sama dalam kriteria tafsir kontekstual disebutkan oleh Solahudin dengan orientasi makna yang relevan dengan kebutuhan masyarakat modern. ${ }^{73}$ Kontekstualitas dalam penafsiran dapat berlangsung dengan penggunaan rasionalitas dalam memberikan pemahaman terhadap pemaknaan ayat.

Penjelasan penggunaan rasionalitas dalam penafsiran dalam tafsir karya Surin berdampak pada pengungkapan nilai-nilai kontekstual yang terdapat dalam karya ini. Penelitian yang ada tidak memberikan eksplorasi yang mendalam terhadap karya tafsir yang dihasilkan oleh Surin. Penjelasan yang hanya sekilas dalam beberapa kajian tafsir Nusantara, baik yang dilakukan oleh

${ }^{70}$ Surin, Terjemah \& Tafsir Al-Qur'an Huruf Arab \& Latin, 258.

${ }^{71}$ Surin, 10.

72 Zaghlūl Al-Najjār, al-'Ard’u fì al-Qur'an al-Karìm (Beirut: Dār al-Ma'rufah, 2005), 69.

73 Solahudin, "Pendekatan Tekstual Dan Kontekstual Dalam Penafsiran Alquran."

192 | TAJDID Vol. 20, No. 2, Juli - Desember 2021 
Federspiel $^{74}$, Baidan ${ }^{75}$, Gusmian ${ }^{76}$, dan Zurdi $^{77}$ menjadikan nilai tafsir ini tidak relevan dalam kontribusinya terhadap pembangunan pengetahuan umat Islam di Indonesia. Nuansa rasionalitas yang dibangun oleh Surin memiliki nilai yang signifikan untuk menjawab perdebatan penggunaan akal dalam wilayah penafsiran. Akal sebagai bagian dari anugrah Tuhan dapat digunakan untuk memberikan pengertian atas al-Qur'an yang juga berasal dari Tuhan. Kriteria akal yang diberikan oleh Surin sebagai akal yang termanifestasi ilmu pengetahuan sebagai perangkat dalam memahami al-Qur'an tidak menyalahi konsep penggunaan akal yang ditetapkan oleh banyak ulama studi al-Qur'an. ${ }^{78}$ Rasionalitas ini justru meletakkan tafsir Surin sebagai bagian dari upaya memberikan pemahaman al-Qur'an yang relevan terhadap umat Islam di Indonesia.

Pengungkapan atas makna yang relevan terhadap konteks dalam kajian tafsir kontekstual selalu mengarah pada penemuan signifikansi ayat yang relevansi terhadap konteks kekinian. Hal tersebut dijadikan batasan dalam setiap pemahaman kontekstual. Pesan utama (signifikansi) menjadi ukuran pasti dalam memberikan perubahan atas makna yang sesuai dengan konteks masa modern. ${ }^{79}$ Langkah ini mengabaikan peran subjektif penafsir yang dapat berkontribusi dalam upaya penafsiran al-Qur'an secara kontekstual. Penafsir dengan konsep pengetahuan yang dimiliki memungkinkan untuk memberikan analisa terhadap suatu ayat dengan tetap menjaga relevansi makna yang sesuai dengan pengetahuan tersebut.

${ }^{74}$ Federspiel, Kajian Al-Qur'an Di Indonesia: Dari Mabmud Yunus Hingga Qurasih Shibab.

75 Nashruddin Baidan, Perkembangan Tafsir Al-Qur'an Di Indonesia (Solo: Tiga Serangkai, 2003).

${ }^{76}$ Gusmian, Khazanah Tafsir Indonesia, Dari Hermeneutika Hingga Ideologi. Kontekstualisasi.

77 Zuhdi, Pasaraya Tafsir Indonesia: Dari Kontestasi Metodologi Hingga

78 Al-Dhahabī, al-Tafsì wa al-Mufassirūn; Taymiyah, Muqaddimah fi Usul alTafsìr, Al-Zurqānī, Manāhil al-'Irfān.

79 Syamsuddin, Pendekatan Ma Nä-Cum-Maghzā Atas Al-Qur'an Dan Hadis: Menjawab Problematika Sosial Keagamaan Di Era Kontemporer. 
Penguasaan atas ilmu pengetahuan modern akan berdampak pada penafsiran atas ayat yang relevan dengan konteks perkembangan masyarakat modern tanpa harus terikat dengan signifikansi ayat. Makna ayat akan terus berkembang yang kemudian ditangkap oleh akal yang dilengkapi oleh ilmu pengetahuan untuk mencapai makna yang relevan dengan konteks kekinian. Hal ini juga diungkapkan oleh Derrida dengan menyebutkan makna yang dari teks akan selalu berkembang yang diciptakan oleh hasil kreatif pembaca tanpa ada batas dan tanpa ada batasan. ${ }^{80}$ Memasukkan subjektivitas dalam kerangka tafsir kontekstual dapat memberikan pemahaman yang lebih mudah terhadap narasi al-Qur'an dengan kesesuaiannya dengan konteks dan perkembangan ilmu pengetahuan.

\section{Penutup}

Penafsiran kontekstual yang selama ini didasarkan pada pesan utama (signifikansi) yang terkandung dalam sebuah ayat tidak menjadi satu-satunya cara. Penelitian ini justru menunjukkan lain dalam memahami al-Qur'an secara kontekstual berdasarkan rasionalitas yang dimiliki oleh penafsir dengan menggunakan perangkat keilmuan yang dimiliki. Upaya penafsiran semacam ini termasuk dalam aliran subjektif yang sebelumnya tidak ditekankan pada produk tafsir yang dihasilkan. Subjektifitas dalam penafsiran selalu diperdebatkan dalam segi prosesnya. Rasionalitas yang dimiliki setiap penafsir dengan segala kompleksitas pembentuknya menjadikan hasil pemahaman terhadap al-Qur'an memiliki relevansi dengan konteks kekinian. Hal ini disebabkan oleh keberadaan pengetahuan yang aktual dalam diri seorang penafsir menuntut penafsiran ke arah yang sesuai dengan perkembangan pengetahuan tersebut. Kontektualitas penafsiran dapat ditempuh dengan menggunakan pendekatan rasional yang dapat menghasilkan pemahaman yang kontekstual.

${ }^{80}$ Jacques Derrida, Of Grammatology, trans. Gayatri C. Spivak (Baltimore: The Johns Hopkins University Press, 1976), xii.

194 | TAJDID vol. 20, No. 2, Juli - Desember 2021 
Kontektualitas dalam pemahaman al-Qur'an dengan menggunakan perangkat rasional dihasilkan melalui pengaplikasian content analysis sebagai perangkat analisa data. Perangkat ini memungkinkan untuk melakukan penelusuran atas hasil penafsiran kontekstual yang dilakukan oleh Surin yang bertebaran di berbagai ayat. Penarikan kesimpulan melalui data-data tersebut juga dimungkinkan untuk ditarik satu kesimpulan yang kemudian dilakukan pengeneralisiran atas kesimpulan tersebut sebagai satu konsep utuh dalam penafsiran Surin terhadap al-Qur'an. Meskipun demikian, penelitian ini yang hanya membatasi data pada Terjemah dan Tafsir al-Qur'an bahasa Arab dan Latin karya Bachtiar Surin membutuhkan kajian lanjutan. Aspek kontekstual lainnya yang terkandung dalam penafsiran dengan model yang sama dibutuhkan untuk menguatkan atau memberikan kritik atas hasil penelitian ini. Narasi-narasi kontekstual yang dilakukan dengan cara lain di luar penemuan atas signifikansi ayat juga dibutuhkan untuk memberikan perspektif lain dalam pengembangan kajian al-Qur'an.

\section{Daftar Pustaka}

Abshor, M. Ulil. "Pendekatan Kontekstualis Dalam Penafsiran AlQur'an (The Study Of Abdullah Saeed's Qur'anic Interpretation)." Al-Adabiya: Jurnal Kebudayaan Dan Keagamaan, 2018. https://doi.org/10.37680/adabiya.v13i02.25.

Afriyandi, Rikho. "Analisis Ujaran Kebencian Dalam Bermedia Sosial: Kajian Atas Semangat Perdamaian Dalam Al-Quran." Journal of Islamic Civilization 3, no. 1 (April 30, 2021): 24-33. https://doi.org/10.33086/JIC.V3I1.1893.

Al-Azharī, Abū Manşūr. Ma'an̄ Al-Qirāāt Li Al-Az̧barì. Vol. 2. Saudi Arabia: Jāmi’ah al-Mulk Su’ūd, 1991.

Al-Biqā̄̄è, Ibrāhīm bin 'Umar. Maşă̄id Al-Nadhar Li Ishrāf 'alā Maqāşid Al-Siwar. Vol. 1. Riyāụ: Maktabah al-Ma'ārif, 1987.

Al-Dhahabī, Muḥammad Husayn. Al-Tafsì Wa Al-Mufassirūn. Vol. 1. Kairo: Maktabah Wahbah, 2007.

TAJDID vol. 20, No. 2, Juli - Desember 2021 | 195 
Al-Ghazālī, Abū Ḥāmid Muḥamamad bin Muḥammad. Ihyaà' 'Ulūm Al-Dìn. Vol. 1. Beirut: Dār al-Ma'rifah, n.d.

Al-Najjār, Zaghlūl. Al-'Arụdu Fì Al-Qur'an Al-Karim. Beirut: Dār alMa'rufah, 2005.

Al-Suyūṭ̂̄, Jalāl al-Dīn. Al-Itqān Fi 'Ulūm Al-Qur'an. Vol. 1. Beirut: al-Hay'ah al-Mişriyah al-'Ammah li al-Kitāb, 1974.

Al-Zurqānī, Muḥammad 'Abd al-'Az\}īm. Manāhil Al-'Irfān. Vol. 2. Beirut: Dār al-Fikr, 1988.

Ardiansyah, Rian. "Konsep Akal Dalam Tafsir Al-Misbah.” UIN Raden Intan Lampung, 2018.

Arifin, Mochammad. "Epistemologi Rasionalisme Rene Descartes Dan Relevansinya Terhadap Penafsiran Al-Qur'an." Jurnal Ilmiah Ilmu Ushuluddin 17, no. 2 (December 1, 2018): 147-57. https://doi.org/10.18592/JIU.V17I2.2240.

Arkoun, Mohammed. "The Notion of Revelation: From Ahl AlKitab to the Societies of the Book." Die Welt Des Islams 28, no. $1 / 4$ (1988): 62. https://doi.org/10.2307/1571165.

Azizy, Jauhar, Moh. Anwar Syarifuddin, and Hani Hilyati Ubaidah. "Thematic Presentations in Indonesian Qur'anic Commentaries." In Proceedings of the 1st International Conference on Recent Innovations - ICRI, 1962-69. Jakarta: Scitepress, 2020. https://doi.org/10.5220/0009937919621969.

Badruzaman, Abad. "Toward an Indonesian Current in Islamic Exegesis: An Attempt to Contextualize the Maqasid AlQuran." Journal of Indonesian Islam, 2019. https://doi.org/10.15642/JIIS.2019.13.2.505-524.

Baidan, Nashruddin. Perkembangan Tafsir Al-Qur'an Di Indonesia. Solo: Tiga Serangkai, 2003.

Dakroury, Aliaa Ibrahim. "Toward a Philosophical Approach of the Hermeneutics of the Qur'an." American Journal of Islamic Social Sciences 23, no. 1 (2006): 15-34. https://doi.org/10.35632/ajiss.v23i1.433.

Derrida, Jacques. Of Grammatology. Translated by Gayatri C. Spivak. Baltimore: The Johns Hopkins University Press, 1976. 
Esack, Farid. Quran, Leberation and Pluralism: An Islamic Perspective of Interreligious Solidarity Againt Oppression. London: Oneworld Publication, 1997.

Faraz, Muhammad Samiullah, and Syeda Asiya. "Impact of the Contextual Approach on the Qur'ānic Interpretations: An Analytical Study." Jihat Ul Islam 14, no. 1 (December 27, 2020): 1-20. https://doi.org/10.51506/JIHAT-ULISLAM.V14I1.167.

Federspiel, Howard M. Kajian Al-Qur'an Di Indonesia: Dari Mabmud Yunus Hingga Qurasih Shibab. Translated by Tajul Arifin. Bandung: Mizan, 1996.

Gusmian, Islah. Khazanah Tafsir Indonesia, Dari Hermeneutika Hingga Ideologi. Yogyakarta: LKiS, 2013.

Kadir, Abdul. "Genetika Dalam Perspektif Al-Quran Studi Analisis Perbandingan Penafsiran Ayat Genetika Kecerdasan Dan Konsep STIFIn.” Pascasarjana Institut Ilmu Al-Qur'an (IIQ) Jakarta, 2019. http://repository.iiq.ac.id//handle/123456789/201.

Khan, Diwan Taskheer. "Mutazilaism: An Introduction to Rationality in Islam." International Journal of Engineering and Applied Sciences 4, no. 10 (2017): 257359. https://doi.org/10.0/CSS/ALL.CSS.

Khan, Waseem, and Hafeez Ullah Khan. "The Gulen Movement: The Blending of Religion and Rationality." Journal of Research in Social Sciences (JRSS) 6, no. 1 (January 2018).

Larsen, Jeppe Fuglsang. "Reinstating and Contextualizing Religion in the Analysis of Islamist Radicalization in the West." Distinktion: Journal of Social Theory 22, no. 2 (2021): 192-209. https://doi.org/10.1080/1600910X.2021.1885050.

Miles, Matthew B., and A. Michael Huberman. Qualitative Data Analysis (a Source Book of New Methods). Beverly Hills: SAGE Publications, 1984.

Muqowim, and Zulkipli Lessy. "Augmenting Science in the Islamic Contemporary World: A Strategic Attempt at Reconstructing the Future." Al-Jami'ab: Journal of Islamic Studies 57, no. 1

TAJDID vol. 20, No. 2, Juli - Desember 2021 | 197 
June 29, 2019): $197-230$. https://doi.org/10.14421/AJIS.2019.571.197-230.

Rahbar, Muhammad Daud. "The Challenge of Modern Ideas and Social Values to Muslim Society." The Muslim World 48, no. 4 (October 1958): 274-85. https://doi.org/10.1111/j.14781913.1958.tb02579.x.

Rahman, Fazlur. Islam and Modernity: Transformation of an Intellectual Tradition. Chicago: University of Chicago Press, 1979.

Reda, Ayman. "Islam, Rationality, and Self-Interest." Prophecy, Piety, and Profits, 2018, 303-35. https://doi.org/10.1057/978-1137-56825-0_21.

Rippin, Andrew. Muslims: Theor Religious Beliefs and Practices. Vol. 2. New York: Routledge, 1993.

Rosyada, Dede. "A Contextual Method of Interpreting the Qur'an: A Search for The Compatibility of Islam and Modernity." In Proceedings of the International Conference on Qur'an and Hadith Studies (ICQHS) , 1-6. Atlantis Press, 2017. https://doi.org/10.2991/ICQHS-17.2018.1.

Saeed, Abdullah. Al-Qur'an Abad 21: Tafsir Kontekstual. Translated by Ervan Nurtawab. Bandung: Mizan, 2016.

Sheedy, Matt. "Habermas, Islam, and Theorizing the 'Other':" Critical Research on Religion 6, no. 3 (October 14, 2018): 33150. https://doi.org/10.1177/2050303218800377.

Solahudin, M. "Pendekatan Tekstual Dan Kontekstual Dalam Penafsiran Alquran." Al-Bayan: Jurnal Studi Ilmu Al-Qur'an Dan Tafsir 1, no. 2 (December 30, 2016): 115-30. https://doi.org/10.15575/al-bayan.v1i2.1596.

Sukino, Sukino, Wahab Wahab, and Ahmad Fauzi Murliji. "Development and Contextualization of Multicultural Insight-Based Quran Hadith Materials in Madrasah Aliyah." Edukasia: Jurnal Penelitian Pendidikan Islam 15, no. 2 (August 30 , 2020): 293-314. https://doi.org/10.21043/EDUKASIA.V15I2.8045.

Surin, Bachtiar. Terjemah \& Tafsir Al-Qur'an Huruf Arab \& Latin. Bandung: Penerbit Fa. Sumatra, 1978. 
Syamsuddin, Sahiron. Hermeneutika Dan Pengembangan Ulumul Quran. Yogyakarta: Pesantren Newesea Press, 2017.

"Ma'Na-Cum-Maghza Approach To The Qur'an: Interpretation Of Q. 5:51." In International Conference on Qur'an and Hadith Studies (ICQHS 2017), 137:131-36. Atlantis Press, 2018.

—. Pendekatan Ma Nà-Cum-Maghzà Atas Al-Qur'an Dan Hadis: Menjawab Problematika Sosial Keagamaan Di Era Kontemporer. Yogyakarta: Lembaga Ladang Kata, 2020.

Taymiyah, Ibn. Muqaddimah Fi Ușul Al-Tafsìr. Beirut: Dār Maktabah al-Hayāh, 1980.

Zuhdi, M. Nurdin. Pasaraya Tafsir Indonesia: Dari Kontestasi Metodologi Hingga Kontekstualisasi. Yogyakarta: Kaukaba, 2014. 